\title{
Prevalence, source and severity of work-related injuries among "foreign" construction workers in a large Malaysian organisation: a cross-sectional study
}

\author{
Haroun ZERGUINE ${ }^{1 *}$, Shamsul Bahri Mohd TAMRIN ${ }^{1}$ and Juliana JALALUDIN ${ }^{1}$ \\ ${ }^{1}$ Department of Environmental and Occupational Health, Faculty of Medicine and Health Science, \\ University Putra Malaysia, Malaysia
}

Received November 19, 2017 and accepted January 26, 2018

Published online in J-STAGE February 2, 2018

\begin{abstract}
Malaysian construction sector is regarded as critical in the field of health because of the high rates of accidents and fatalities. This research aimed to determine the prevalence, sources and severity of injuries and its association with commitment to safety among foreign construction workers. A cross-sectional study was conducted among 323 foreign construction workers from six construction projects of a large organization in Malaysia, using a simple random sampling method. Data was collected using a structured questionnaire to assess work-related injuries and safety commitment. The collected data was analysed by SPSS 22.0 using descriptive statistics and $\chi^{2}$ test. The prevalence of work-related injuries in a one year period was $22.6 \%$, where most of the injuries were of moderate severity (39.7\%) and falls from heights represented the main source $(31.5 \%)$. The majority of the foreign construction workers had perceived between moderate and high safety commitment, which was significantly associated with work-related injuries. The results also showed a significant association of work-related injuries with the company's interest in Safety and Health, Safety and Health training, and safety equipment. Thus, the implementation of new procedures and providing relevant trainings and safety equipment; will lead to a decrease in injury rates in construction sites.
\end{abstract}

Key words: Injuries, Construction, Foreign workers, Safety, Health

\section{Introduction}

The construction sector is one of the largest sectors in many parts of the world, playing a fundamental role in the development process of a country ${ }^{1}$. The vast contributions of the construction sector to Malaysia's economy have made it a very important sector, where research based on

*To whom correspondence should be addressed. E-mail: zerguine.har_hse@yahoo.fr

(C)2018 National Institute of Occupational Safety and Health statistics has shown a strong positive correlation between the construction sector and the economic growth of Malaysia by a correlation coefficient of $0.65^{2)}$. However, the full potential of economic growth that can be achieved by the construction industry is inhibited by occupational risks and high rates of accidents and injuries ${ }^{3)}$. The construction sector has been described as one of the most hazardous industries of all sectors, as measured by injury and fatality rates ${ }^{4}$. Accidents in the construction sector occur at a substantially higher rate than in most other sectors and with severe consequences, both for the workers and the 
public ${ }^{5}$. Based on the statistics issued by Social Security Organization (SOCSO) Malaysia, Chong \& Low have found that the number of fatality and permanent disabilities caused by falls from heights in high-rise building projects is one of the highest rates as compared to other sectors $^{6}$, due to the nature of construction work: work is done outside under the hot sun or in the rain; workers are required to climb to high places such as roofs, ladders, and scaffolding; and the use of dangerous tools, heavy materials, hazardous machinery and dangerous equipment also increases the risk to workers' safety and health. All these inherent hazards, and the nature of the jobs performed by workers, made the Malaysian construction sector contribute to total highest death cases in 2016 (106 cases) and the third highest rate of non-permanent disability (135 cases) as compared to other sectors ${ }^{7}$.

The factors influencing the occurrence of construction accidents and injuries have been pointed out in the construction engineering and management literature ${ }^{8)}$. Many studies have classified the contributing causes of construction accidents into human and physical factors ${ }^{8,9)}$. While there are various sources, accidents result from a combination of contributing causes from the workers, the company or both sides ${ }^{10)}$. The causes behind accidents in the Malaysian construction sector were reviewed, and findings revealed that the two major causes of accidents were management failure in implementing and maintaining a high safety management system at the company, and incorrect work procedures by the employees resulting in unsafe methods ${ }^{11)}$. In fact, commitment to safety is represented through good site management, where the workers' perception of safety commitment from the company is a major factor that influences the occurrence of injuries in the workplace ${ }^{12)}$. Management commitment remains an important element to be investigated in safety research, where a high level of safety commitment from management reduces the rate of workplace accidents and injuries ${ }^{13,14)}$. The two most important determinants in workforce satisfaction with regard to safety and a low accident rate are commitment to safety and the organizational support provided by management ${ }^{15}$. Moreover, research showed that management is the responsible for improving working conditions and preventing accidents or incidents from occurring ${ }^{16)}$. Therefore, this study intended to test the hypothesis of the existence of a significant association between safety commitment and work-related injuries.

The Department of Statistics in Malaysia has shown that the construction industry directly employed approximately $1,214,000-12,116,600$ workers, thereby taking up $10 \%$ of the country's total employment, where around $70-80 \%$ are occupied by foreigners, excluding illegal labourers ${ }^{17)}$. Poor monitoring of foreign employment requirements and procedures by the authorities has contributed to the flow of foreign labourers in the construction sector, where many employers choose to hire foreign workers due to their willingness to work under harsh conditions for lower salary ${ }^{18)}$. Most of studies on construction Safety and Health in Malaysia were conducted among general construction workers. Hence, the novelty of this project is in the specificity of the population being investigated by only selecting "foreigners" construction workers. Therefore, the study intended to determine the 12-month prevalence, source and severity of work-related injuries among foreign construction workers and to assess the association between the workers' perception of their employer's safety commitment and the prevalence of work-related injuries.

\section{Subjects and Methods}

\section{Study design, location and period}

A cross-sectional study was conducted to determine the prevalence and sources of work-related injuries among foreign construction workers in the Klang valley. Klang Valley is the area in central Selangor, Malaysia, which has the largest growing economy during the last five years, thus this area was chosen to conduct the study. Four construction organisations have been contacted for data collection, but only one large organisation approved our request to conduct this study among the construction workers. The organisation is committed to be leading conglomerate by providing an outstanding Safety and Health standards and practices to create a safe and healthy workplace for its employees. Six high-rise construction projects were accommodated in this study. Data was collected between June 2016 and September 2016.

\section{Sampling population}

All male foreign workers who had been involved with the construction organisation in the previous year were included in the study until the required sample size was obtained. The organisation declared that a total of 2,040 skilled and unskilled construction workers were working on their construction sites performing different tasks (Framing, Roofing, Plumbing, Electrical, Flooring, and Painting) at that time. There was no female worker at the selected construction sites, and workers who were absent or refused to participate in the study were excluded. 


\section{Sample size and sampling procedure}

The required sample size was determined by using one population proportion formula. For the calculation, 95\% confidence level, 5\% marginal error and 50\% injury prevalence, in order to maximize the sample size, were assumed. The sample size was adjusted according to the total population size ${ }^{19}$. Based upon the locations of the construction sites, the study populations were stratified into six different sites. The number of samples from each site was determined by using a proportional allocation formula. Finally, a simple random sampling technique was employed to select a total of 323 respondents from the six construction sites.

\section{Data collection method}

Data was collected through a self-reported survey from June to September 2016, where a structured questionnaire in both English and Malay languages was used. Questionnaire was developed based on the main elements of NOSACQ-50 on Safety Climate ${ }^{20)}$, and the questionnaire used in the study conducted Choudhry ${ }^{21)}$. The questionnaire on socio-demographic characteristics, injury prevalence and safety commitment were extracted and discussed with academics and researchers and modified to be suitable for our target population (Appendix 1). Pilot study was conducted before data collection. The researchers had conducted an early visit to each site to make further arrangements with the project managers. Data collection occurred across two sessions per day for a total of 30 sessions along the data collection, in which 10-12 participants were involved for each session to achieve the required sample size. Indonesian and Bangladeshi language translators were available during all the sessions of the data collection process. Each question was explained separately to allow workers to answer the questions properly, and participants spent 10 to 12 min filling out the questionnaire.

\section{Pilot study}

The questionnaire was constructed in English and translated to the Malay language based on the guidelines provided by the international organization, Consensus Group. "Forward" and "backward" translations were performed on the questionnaire for the English version ${ }^{22)}$. Indonesian and Bangladeshi translators participated throughout the data collection process. Translators were bilingual and trained to translate the questions and assist the respondents with filling out the questionnaire, based on their nationality and their understanding. The face validity of this questionnaire was ensured by a focus group discussion (FGD), where specialists and experts from different companies in the safety field had gathered, and the questionnaire was discussed with the researchers and academics. A test-retest method was used on 30 workers in a construction project which had similar characteristics, to ensure the understanding of the questionnaire and to evaluate its reliability. The reliability of this study was evaluated by calculating the internal consistency of the scales using the Pearson correlation coefficient with an interval of one week ${ }^{23)}$. The results showed that most of the correlation coefficient values were between 0.839 and 1.00 , which demonstrated a strong association that reflects a good reliability levels test-retest.

\section{Ethical consideration}

The study was carried out with the approval of the Ethical Committee for Research Involving Human Subjects of University Putra Malaysia. Permission to conduct the research at the construction sites was granted by the management committee of the construction organisation. Respondents were given a subject information sheet and consent form in order to obtain their voluntary participation in this study.

\section{Data analysis}

The data collected was coded and analysed using the Statistical Package of Social Science (SPSS for Windows, Version 22.0, 2016). Descriptive statistics were used to summarize and explain the characteristics of the variables as frequency and percentage. The $\chi^{2}$ test/Fisher's exact test was used to assess the association between safety commitment variables and work-related injuries.

\section{Results}

\section{Socio-demographic characteristics}

A total of 323 questionnaires were distributed to the six construction sites in Klang Valley. The researcher ensured that all of the questionnaires were answered, and workers who did not wish to participate in the study were replaced by other respondents to achieve the target of $100 \%$ response rate.

The age of the majority of the respondents was between 20 and $40 \mathrm{yr}$ old $(89.2 \%, \mathrm{n}=288)$ and $47.1 \%$ were married $(\mathrm{n}=152)$. The foreign construction workers were mainly from Bangladesh (48\%) and Indonesia (39\%). Their education levels ranged from not having attended school to tertiary education where $39.9 \%$ had achieved secondary education and $52.7 \%$ had less than secondary level educa- 
Table 1. Socio-demographic characteristics of the foreign construction workers $(\mathrm{N}=\mathbf{3 2 3})$

\begin{tabular}{|c|c|}
\hline Socio-demographic characteristics & Frequency n (\%) \\
\hline \multicolumn{2}{|l|}{ Age (yr) } \\
\hline$<20$ & $9(2.8)$ \\
\hline $20-40$ & $288(89.2)$ \\
\hline$>40$ & $26(8)$ \\
\hline \multicolumn{2}{|l|}{ Marital status } \\
\hline Single & $117(36.2)$ \\
\hline Married & $152(47.1)$ \\
\hline Divorced/Windowed & $54(16.7)$ \\
\hline \multicolumn{2}{|l|}{ Nationality } \\
\hline Indonesian & $126(39)$ \\
\hline Bangladeshi & $155(48)$ \\
\hline Pakistan & $25(7.7)$ \\
\hline Nepal & $11(3.4)$ \\
\hline China & $6(1.9)$ \\
\hline \multicolumn{2}{|l|}{ Education level } \\
\hline Not attending school & $50(15.5)$ \\
\hline Primary education & $120(37.2)$ \\
\hline Secondary education & $129(39.9)$ \\
\hline College or higher & $24(7.4)$ \\
\hline \multicolumn{2}{|l|}{ Working Experience in Malaysia } \\
\hline $1-2 \mathrm{yr}$ & $44(13.6)$ \\
\hline $2-3 \mathrm{yr}$ & $127(39.3)$ \\
\hline $3-5 \mathrm{yr}$ & $67(20.7)$ \\
\hline More than $5 \mathrm{yr}$ & $85(26.3)$ \\
\hline \multicolumn{2}{|l|}{ Qualification } \\
\hline Yes & $274(84.8)$ \\
\hline No & $49(15.2)$ \\
\hline
\end{tabular}

tion. Overall, the respondents had worked in Malaysia for between two and three years (39.3\%). Most of the workers $(84.8 \%)$ had a qualification in their current work. Table 1 shows the socio-demographic characteristics among foreign construction workers.

\section{2 months prevalence of work-related injuries}

12 months prevalence of work-related injuries was $22.6 \%(n=73)$, of which $85.1 \%(n=63)$ were reported to the organisation. Majority of work-related injuries were between moderate $(39.7 \%)$ and minor $(42.5 \%)$. Table 2 shows the prevalence and severity of work-related injuries among foreign construction workers.

\section{Sources of work-related injuries}

Falls from heights ( 6 feet or more above lower level) were recorded as the highest source of work-related injuries $(31.5 \%)$ followed by lifting and handling (24.7\%). Figure 1 shows bar chart of sources of work-related inju-

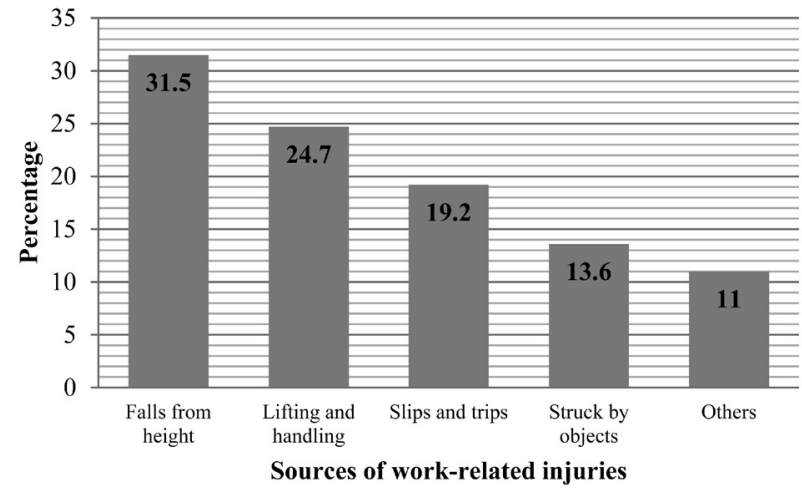

Fig. 1. Sources of work-related injuries reported by foreign construction workers.

ries reported by foreign construction workers.

Falls from heights were the first source of serious and moderate work-related injuries by $69.2 \%$ and $40.6 \%$ successively, while slips and trips were the first source (39.3\%) for minor injuries. Table 3 shows the sources and severity of work-related injuries reported by foreign construction workers.

\section{Safety commitment and work-related injuries}

The perception of workers on the attitudes and practices performed by the organisation's management reflects the best dimensions of safety commitment. Respondents differentiated between low, moderate and high levels of safety commitment by the organisation. A $\chi^{2}$ test was performed and, according to the results presented in Table 4, workers who assumed that the company's safety commitment was at a high level had a lower number of injuries, and there was a statistically significant association between safety commitment and work-related injuries $\left(\chi^{2}=6.726, p=0.035\right)$. Furthermore, the details showed that work-related injuries were significantly associated with the company's interest in Safety and Health $\left(\chi^{2}=10.896\right.$, $p=0.001)$, Safety and Health training $\left(\chi^{2}=12.007, p=0.001\right)$ and Safety equipment $\left(\chi^{2}=11.051, p=0.001\right)$. On the other hand, there was no significant association between workrelated injuries and tools and machinery.

\section{Discussion}

The rate of injuries among construction workers is becoming an important issue in the Malaysian construction sector because of the high number of accidents, low awareness of workers and low commitment to safety from some companies. This study revealed that out of 323 par- 
Table 2. Prevalence of work-related injuries among foreign construction workers

\begin{tabular}{lcc}
\hline Work-related injuries & Frequency $(\mathrm{n})$ & Percentage (\%) \\
\hline Yes & 73 & 22.6 \\
No & 250 & 77.4 \\
Total & 323 & 100 \\
Reported (n=73) & & \\
$\quad$ Yes & 63 & 85.1 \\
$\quad$ No & 10 & 14.9 \\
Severity (n=73) & & \\
$\quad$ Serious & 13 & 17.8 \\
$\quad$ Moderate & 29 & 39.7 \\
$\quad$ Minor & 31 & 42.5 \\
\hline
\end{tabular}

Table 3. Sources and severity of work-related injuries reported by foreign construction workers

\begin{tabular}{llllc}
\hline \multicolumn{1}{c}{ Sources } & \multicolumn{4}{c}{ Frequency n (\%) } \\
\cline { 2 - 5 } \multicolumn{1}{c}{ Severity } & Serious & Moderate & Minor & Total \\
\hline Falls from height & $9(69.2)$ & $13(40.6)$ & $1(3.6)$ & $23(31.5)$ \\
Lifting and handling & $2(15.4)$ & $11(34.4)$ & $5(17.9)$ & $18(24.7)$ \\
Slips and trips & $1(7.7)$ & $2(6.3)$ & $11(39.3)$ & $14(19.2)$ \\
Struck by objects & $1(7.7)$ & $5(15.6)$ & $4(14.3)$ & $10(13.7)$ \\
Others & $0(0)$ & $1(3.1)$ & $7(25)$ & $8(11)$ \\
\hline
\end{tabular}

Table 4. The association between safety commitment and work-related injuries

\begin{tabular}{llrrrr}
\hline \multirow{2}{*}{ Variables } & & \multicolumn{2}{c}{ Work-related injuries } & \multirow{2}{*}{$\chi^{2}$} & \multirow{2}{*}{$p$ value } \\
\cline { 3 - 4 } & & \multicolumn{1}{c}{ No } & \multicolumn{1}{c}{ Yes } & & \\
\hline Company interest to Safety and Health & No & $7(43.8)$ & $9(56.3)$ & 10.896 & $0.001^{* *}$ \\
& Yes & $243(79.2)$ & $64(20.8)$ & & \\
Safety Equipment & No & $14(58.3)$ & $10(41.7)$ & 11.051 & $0.001^{* *}$ \\
& Yes & $239(79.4)$ & $62(20.6)$ & & \\
Tools and machinery & No & $12(57.1)$ & $9(42.9)$ & 2.341 & 0.126 \\
& Yes & $238(78.8)$ & $64(21.2)$ & & \\
Safety and Health trainings & No & $15(51.7)$ & $14(48.3)$ & 12.007 & $0.001 * *$ \\
& Yes & $235(79.9)$ & $59(20.1)$ & & \\
\hline Safety commitment & Low & $3(42.9)$ & $4(57.1)$ & 6.726 & $0.035^{* *}$ \\
& Moderate & $90(82.6)$ & $19(17.4)$ & & \\
& High & $157(75.8)$ & $50(24.2)$ & & \\
\hline
\end{tabular}

**Significant at 0.05 level.

ticipants, $22.6 \%$ of the foreign construction workers had experienced work-related injuries at least once in the previous one-year recall period. This finding was similar to the study done in India, where the prevalence rate of injury among construction workers was $22.92 \%{ }^{24)}$. However, this result was higher than the study in Egypt $(18.4 \%)^{25)}$ and lower than the study in Ethiopia $(38.3 \%)^{26)}$. This inconsistency in the prevalence of work-related injuries might be related to the differences between countries in the degree of development, quality of workforce, power of the Occupational Safety and Health laws, diversity of work tasks and complexity of the working conditions. Another reason might be linked to the study population in terms of education level and nationality of the workers; the respondents in this study were all foreign workers, as the Malaysian construction sector is represented by $69 \%$ of foreign workers from the total workforce in this industry ${ }^{27)}$.

$22.9 \%$ prevalence of injuries found in this study can be considered moderate in regards to the reputation of the organisation in terms of safety and health by ensuring a successful implementation of the Occupational Safety and Health Management System (OSHMS). Therefore, the organisation is working to establish a sustainable safety culture at every level among employees and other relevant stakeholders. Moreover, the organisation is making an effort to build a strong safety culture and awareness about hazards among workers by enforcing training requirements and conducting a daily safety toolbox before the start of the day's work. The organisation is also conducting a lot of campaigns aiming to share fundamental messages, which are to "Plan ahead to get the job done and keep safety first", "provide the right equipment" and "train everyone to use the equipment". The construction sites also include posters and safety signboards showing pictures of possible hazards in each working area to constantly remind and warn the workers of the dangers that could befall them 
should they not be vigilant enough. All these efforts from the organisation contribute to a moderate prevalence rate of work-related injuries among their workers.

The findings also show that the majority of the workers who experienced work-related injuries had reported these injuries to the organisation, with only 10 out of 73 respondents not reporting them to the organisation. This finding is congruent with another study in Canada that showed different reasons that may lead workers to neglect to report accidents. The reasons could be related to the concept that employees accept and believe that injuries are part of their job because injuries happen frequently and are of low severity, or it may be because of the fear of losing their job or damaging their reputation ${ }^{28)}$.

The results showed that falls from heights were the main source of work-related injuries by $31.5 \%$, followed by lifting and handling (24.7\%); these two sources were the main contributors to serious and moderate work-related injuries. These results agreed with the statistical data on accidents in the Malaysian construction sector, where falls from heights were the most critical cause of accidents, with an annual average of 1,042 cases $^{6}$. The findings were also similar to many other statistics and studies all over the world: in the USA, fall accidents are considered as the first cause of work-related injuries and fatalities in the construction industry throughout time, where falls from scaffolds, roofs, and ladders represent a major part of fall accidents in the US construction industry ${ }^{29,30)}$. A recent study with similar findings showed that falls from heights had contributed to more than half of the serious injuries (requiring hospitalization) and being struck by objects was ranked as the second cause of serious and moderate injuries ${ }^{31)}$.

Additionally, these findings were consistent with other studies in different countries: in South Korea, it was found that falls from heights comprise the most common source of injuries and death among construction workers ${ }^{32)}$; in South Africa, it was revealed that most of the reported fatalities and injuries were as a result of falling from heights ${ }^{33)}$; and in the USA, similar findings show that falls from high levels are the first cause of injuries and death, followed by being struck by objects, and finally, being caught in or between objects ${ }^{34)}$. Ultimately, in the Malaysian construction sector, falls remain as the source of the highest source of accidents and injuries, despite a gradual decline in occupational accidents.

Based on the results, the safety commitment scores varied according to the respondents' perceptions, with the majority of them showing moderate and high scores for safety commitment. The results justify the efforts of the organisation's management in providing a safe workplace, and keeping safety as a priority on all construction sites. Furthermore, the results revealed a significant association between safety commitment and work-related injuries where workers who perceived a high safety commitment did not experience any work-related injuries. These findings were accordant with another study that found that workers who perceived a high commitment to safety from their management had a lower accident rate ${ }^{15)}$. The management's commitment to safety is significantly associated with the occurrence of injuries over time ${ }^{12)}$. Consequently, these findings supported other studies that showed a significant effect of management's commitment to safety in reducing the number of workplace accidents and injuries ${ }^{35)}$. The hypothesis in this study suggesting a significant association between safety commitment and work-related injuries is true.

In addition, the results also showed that safety equipment was associated with work-related injuries, which supports the study conducted in Malaysia showing that the lack of personal protective equipment (PPE) is considered as one of the main causes of construction accidents ${ }^{11)}$. These results were in accordance with similar studies conducted in the USA, Thailand and Uganda, proving that the lack of safe equipment is considered as a contributing factor to accidents and injuries in construction, as some employers do not provide their workers with the sufficient and correct equipment necessary to minimize hazards ${ }^{12,36,37)}$.

Inversely, this study did not find any significant association between work-related injuries and tools and machinery, as the findings were in disagreement with two studies in the USA and Indonesia that found the availability of tools and machinery can be a predictor of occupational injuries and a contributing factor to safety performance ${ }^{38,39)}$. This variance in the findings might be explained by the differences in commitment of the companies to providing all the tools and machinery necessary to perform the work safely and create safe working conditions. Other reasons might be related to the financial status of each organisation and the types of subcontractors hired to complete specific parts of the project.

\section{Study Limitation}

There are some limitations to this study. Firstly, the study had focused on "Foreign" construction workers of one organisation in Malaysia; therefore, the results were unable to be generalized to all construction sites in Ma- 
laysia. Future studies on different companies and different locations are needed to support or refute our findings. Secondly, the measurement of safety commitment was based on self-reported questionnaire validated by academicians and construction safety experts, thus, the accuracy of this research relies on the honesty and perception of respondents in answering the questions. Lastly, this study relied on self-reported data; thus, bias might exist as well. Information bias might have occurred when filling up the questionnaire due to deferent understanding of the respondents based on their perception and judgment. However, the research team did huge effort to deliver the accurate meaning of each question to the respondents by explaining and using trained translators.

\section{Conclusion}

Injuries among construction workers occur at a substantially higher rate rather than in other sectors. This study conducted among foreign construction workers in six construction sites of a large organisation in Malaysia; revealed that the 12 months prevalence of work-related injuries was $22.6 \%$, where the majority of injuries were between minor and moderate severity. Falls from heights was recorded as the highest source of injuries followed by lifting and handling, and safety commitment was found to be a significant determinant of injury rates at the workplace. These findings could be used by other organisations as a reference to compare number and sources of injuries among foreign construction workers in different locations. Moreover, the further implementation of new procedures and provide relevant trainings and safety equipment will lead to a decrease in accident and injury rates at the workplace. Lastly, there is limited research on this topic and more studies are necessary to reduce the rates of injuries in this sector; therefore, future research could be directed to investigate the contributing factors of injuries among foreign workers.

\section{Acknowledgments}

The authors would like to express their sincere gratitude to RMC and greatly appreciate the cooperation given by the representatives of the organisation in facilitating the data collection process. Authors would like also to thank all safety experts and academicians that have participated in developing and validating the questionnaire.

\section{Funding}

This study is a part of Master research project that was approved by the ethical committee and was funded by the Research Management Centre (RMC), University Putra Malaysia.

\section{Conflict of interest}

The authors declare that there is no potential conflict of interests.

\section{References}

1) Asif M (2016) Growth and sustainability trends in the buildings sector in the GCC region with particular reference to the KSA and UAE. Renew Sustain Energy Rev 55, 1267-73. [CrossRef]

2) Khan RA, Liew MS, Ghazali Z Bin (2014) Malaysian construction sector and Malaysia vision 2020: developed nation status. Procedia Soc Behav Sci 109, 507-13. [CrossRef]

3) Abdullah D, Wern GCM (2011). An analysis of accidents statistics in Malaysian construction sector. In 2010 International Conference on E-Business, Management and Economics 14, 1-4.

4) Pinto A, Nunes IL, Ribeiro RA (2011) Occupational risk assessment in construction industry-overview and reflection. Saf Sci 49, 616-24. [CrossRef]

5) Sousa V, Almeida NM, Dias LA (2014) Risk-based management of occupational safety and health in the construction industry-Part 1: background knowledge. Saf Sci 66, 75-86. [CrossRef]

6) Chong HY, Low TS (2014) Accidents in Malaysian construction industry: statistical data and court cases. Int $\mathrm{J}$ Occup Saf Ergon 20, 503-13. [Medline] [CrossRef]

7) Department of Occupational Safety \& Health (2016). Occupational Accidents Statistics by Sector until December 2016. http://www.dosh.gov.my/index.php/en/archivestatistics/2016/1846-occupational-accidents-statistics-bysector-until-december-2016. Accessed January 10, 2018.

8) Abdelhamid TS, Everett JG (2000) Identifying root causes of construction accidents. J Constr Eng Manage 126, 52-60. [CrossRef]

9) Gibb A, Lingard H, Behm M, Cooke T (2014) Construction accident causality: learning from different countries and differing consequences. Construct Manag Econ 32, 446-59. [CrossRef]

10) Manu PA, Ankrah NA, Proverbs DG, Suresh S (2012) Investigating the multi-causal and complex nature of the accident causal influence of construction project features. Accid Anal Prev 48, 126-33. [Medline] [CrossRef]

11) Hamid ARA, Majid MZA, Singh B (2008) Causes of 
accidents at construction sites. Malays J Civ Eng 20, 242-59.

12) O'Toole M (2002) The relationship between employees' perceptions of safety and organizational culture. J Safety Res 33, 231-43. [Medline] [CrossRef]

13) Flin R, Mearns K, O'Connor P, Bryden R (2000) Measuring safety climate: identifying the common features. Saf Sci 34, 177-92. [CrossRef]

14) Schwatka NV, Hecker S, Goldenhar LM (2016) Defining and measuring safety climate: a review of the construction industry literature. Ann Occup Hyg 60, 537-50. [Medline] [CrossRef]

15) Yule S, Flin R, Murdy A (2006) The role of management and safety climate in preventing risk-taking at work. Int $\mathrm{J}$ Risk Assess Manag 7, 137-51. [CrossRef]

16) Hansez I, Chmiel N (2010) Safety behavior: Job demands, job resources, and perceived management commitment to safety. J Occup Health Psychol 15, 267-78. [Medline] [CrossRef]

17) Department of Statistics Malaysia (2014) Report on survey of construction industries Malaysia 2014. https://www. statistics.gov.my. Accessed March 12, 2017.

18) Hamid ARA, Singh B, Yusof AM, Abdullah NAM (2011) The employment of foreign workers at construction sites. In 2nd International Conference on Construction and Project Management 15:126-132.

19) Cochran WG (1963) Sampling techniques. 2nd Ed., 132, Wiley publications in statistics, New York.

20) Kines P, Lappalainen J, Mikkelsen KL, Olsen E, Pousette A, Tharaldsen J, Tomasson K, Torner M (2011) Nordic Safety Climate Questionnaire (NOSACQ-50): a new tool for diagnosing occupational safety climate. Int J Ind Ergon 41, 634-46. [CrossRef]

21) Choudhry RM (2014) Behavior-based safety on construction sites: a case study. Accid Anal Prev 70, 14-23. [Medline] [CrossRef]

22) Shariat A, Tamrin SBM, Arumugam M, Ramasamy R (2016) The Bahasa Melayu version of Cornell Musculoskeletal Discomfort Questionnaire (CMDQ): reliability and validity study in Malaysia. Work 54, 171-8. [Medline] [CrossRef]

23) Shariat A, Tamrin SBM, Arumugam M, Danaee M, Ramasamy R (2016) Comparative reliability of different instruments used to measure the severity of musculoskeletal disorders in office workers. Work 54, 753-8. [Medline] [CrossRef]

24) Shah CK, Mehta H (2009) Study of injuries among construction workers in Ahmedabad City, Gujarat. Indian J Pract Dr 5, 1-5.

25) Alazab RMA (2004) Work-related diseases and occupational injuries among workers in the construction industry. Afr
Newsl Occup Heal Saf 14, 37-42.

26) Tadesse S, Israel D (2016) Occupational injuries among building construction workers in Addis Ababa, Ethiopia. J Occup Med Toxicol BioMed Cent 11, 1-8.

27) Abdul-Rahman H, Wang C, Wood LC, Low SF (2012) Negative impact induced by foreign workers: evidence in Malaysian construction sector. Habitat Int 36, 433-43. [CrossRef]

28) Curtis Breslin F, Polzer J, MacEachen E, Morrongiello B, Shannon H (2007) Workplace injury or "part of the job"?: towards a gendered understanding of injuries and complaints among young workers. Soc Sci Med 64, 782-93. [Medline] [CrossRef]

29) Huang X, Hinze J (2003) Analysis of construction worker fall accidents. J Constr Eng Manage 129, 262-71. [CrossRef]

30) Dong XS, Choi SD, Borchardt JG, Wang X, Largay JA (2013) Fatal falls from roofs among U.S. construction workers. J Safety Res 44, 17-24. [Medline] [CrossRef]

31) Siddiqui S (2014) US Construction Worker Fall Accidents: Their Causes And Influential Factors. FIU Electronic Theses and Dissertations, 1157.

32) Jeong BY (1998) Occupational deaths and injuries in the construction industry. Appl Ergon 29, 355-60. [Medline] [CrossRef]

33) Chelule PK, Legodi IS (2016) Occurrence of occupational injuries at a railway construction industry in Pretoria, South Africa. Pula Botsw J Afr Stud 30, 65-75.

34) Chi S, Han S, Kim DY (2012) Relationship between unsafe working conditions and workers' behavior and impact of working conditions on injury severity in US construction industry. J Constr Eng Manage 139, 826-38. [CrossRef]

35) Guo BHW, Yiu TW, González VA (2016) Predicting safety behavior in the construction industry: development and test of an integrative model. Saf Sci 84, 1-11. [CrossRef]

36) Alinaitwe HM, Mwakali JA, Hansson B (2007) Factors affecting the productivity of building craftsmen-studies of Uganda. J Civ Eng Manag 13, 169-76.

37) Makulsawatudom A, Emsley M, Sinthawanarong K (2004) Critical factors influencing construction productivity in Thailand. J KMITNB 14, 1-6.

38) Glasscock DJ, Rasmussen K, Carstensen O, Hansen ON (2006) Psychosocial factors and safety behaviour as predictors of accidental work injuries in farming. Work Stress 20, 173-89. [CrossRef]

39) Kaming PF, Olomolaiye PO, Holt GD, Harris FC (1997) Factors influencing construction time and cost overruns on high-rise projects in Indonesia. Construct Manag Econ 15, 83-94. [CrossRef] 


\section{Appendix 1. Questionnaire used in the study}

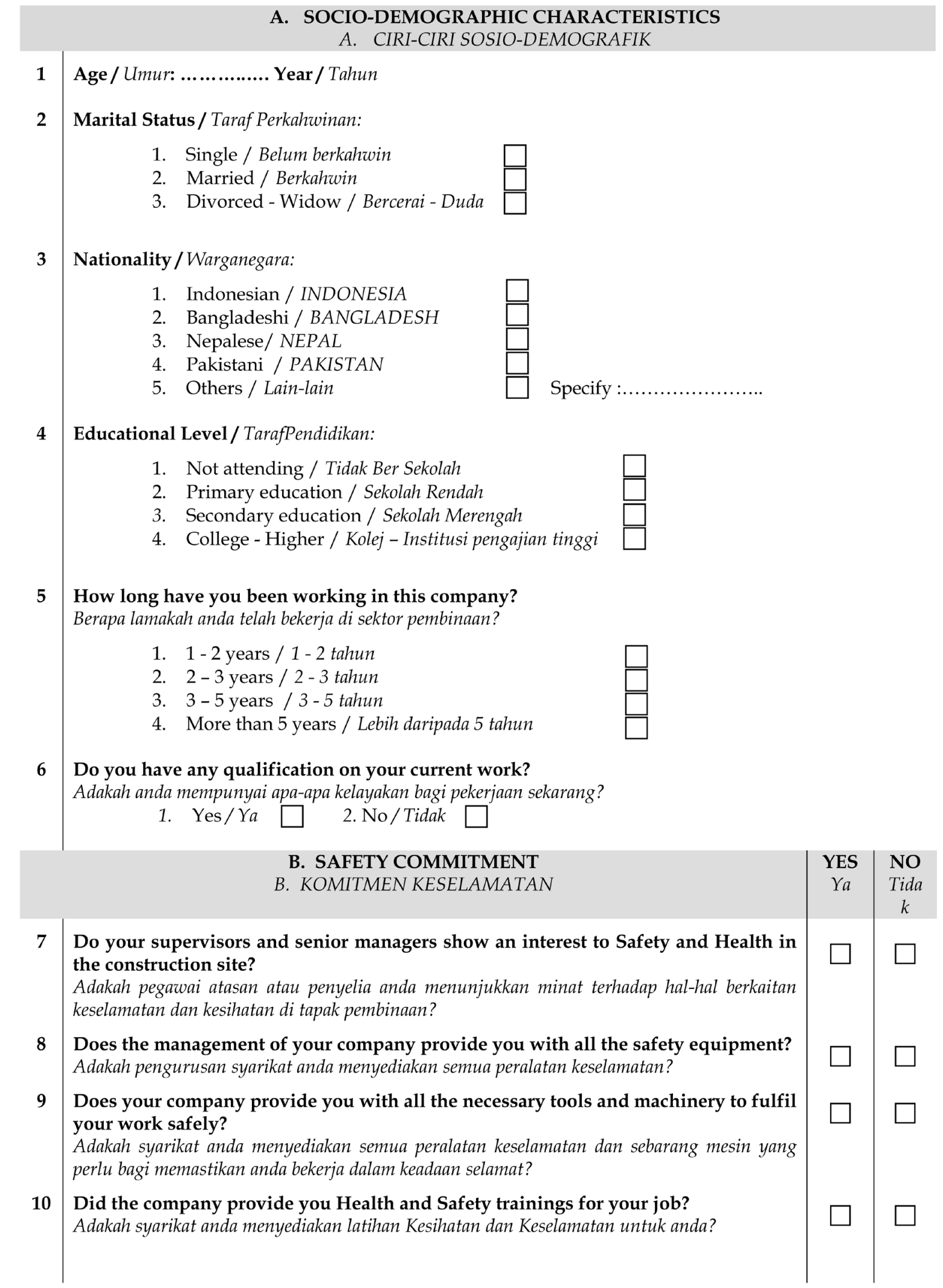




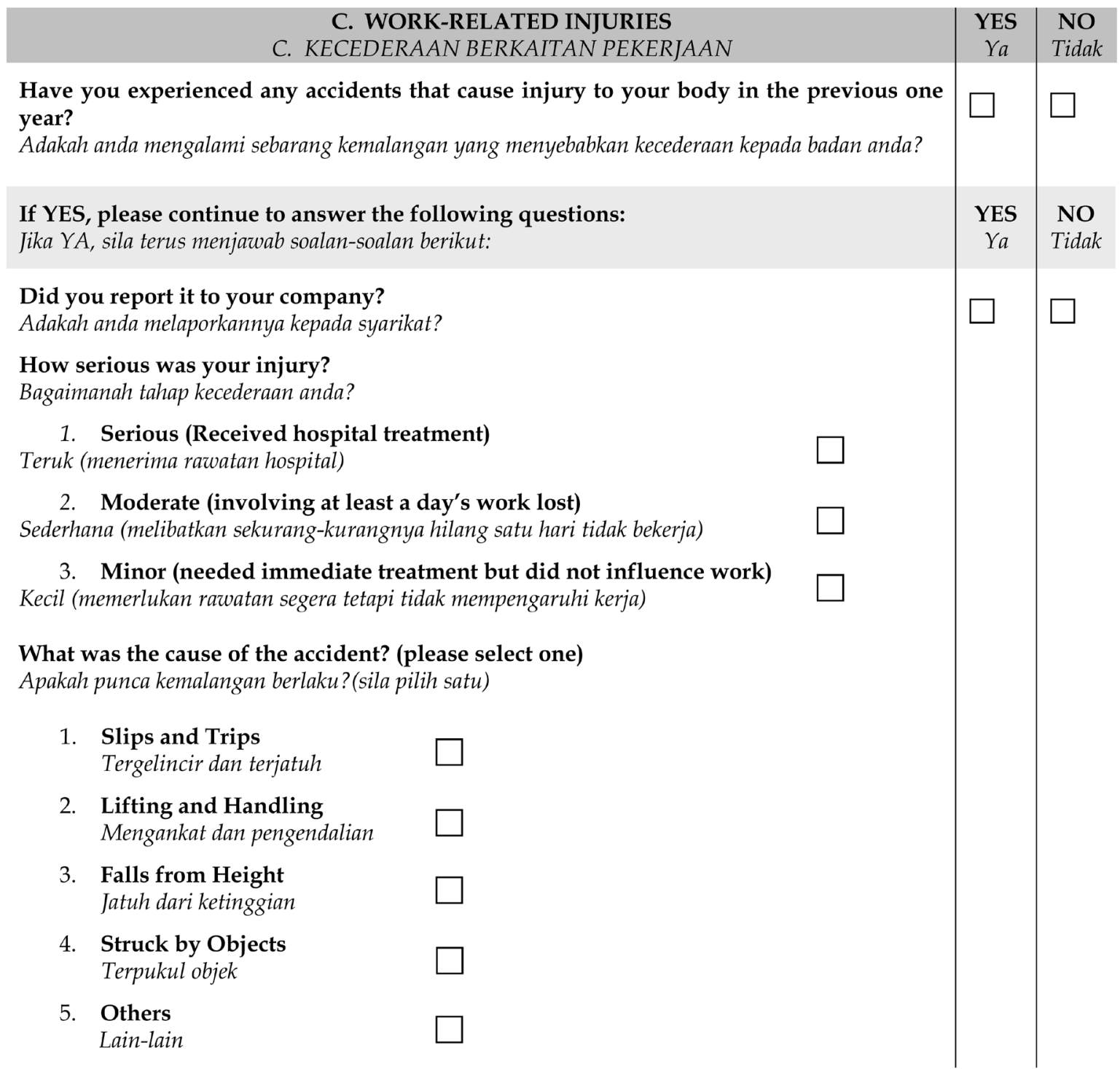

